\title{
Interest Rate and Real Sector Output Growth in Nigeria: Empirical Evidence
}

\author{
Ubong E. Effiong* \\ Department of Economics, University of Uyo, P.M.B. 1017, Uyo, Akwa Ibom State, Nigeria
}

\begin{tabular}{|c|c|}
\hline $\begin{array}{c}\text { Article History } \\
\text { Received: } 20.09 .2020 \\
\text { Accepted: } 09.10 .2020 \\
\text { Published: } 14.10 .2020 \\
\text { Journal homepage: } \\
\text { https://www.easpublisher.com/easjebm } \\
\end{array}$ & $\begin{array}{l}\text { Abstract: This paper examined the effect of interest rate on real sector output growth in } \\
\text { Nigeria through the period } 1985 \text { to } 2019 \text {. Data were obtained from the World Bank } \\
\text { Database on World Development Indicators and the Central Bank of Nigeria Statistical } \\
\text { Bulletin. The data were analysed using Augmented Dickey-Fuller unit root test, Co- } \\
\text { integration, and the Error Correction Mechanism. The unit root test revealed that the } \\
\text { variables were stationary at mixed order of levels and first difference necessitating the } \\
\text { test for co-integration. The co-integration test supported the existence of a long run } \\
\text { equilibrium relationship between interest rate and real sector output growth. Also, } \\
\text { interest rate was observed to exert a negative and significant effect on real sector growth. } \\
\text { Thus, a unit percentage increase in interest rate is likely to lead to a } 0.274 \% \text { decrease in } \\
\text { real sector output growth. The error correction term showed that } 59.9 \% \text { of the short run } \\
\text { disequilibrium in real sector output growth is corrected annually. The paper } \\
\text { recommended a cheap monetary policy that will keep interest rate at a favourable level } \\
\text { so as to encourage investors to borrow. } \\
\text { Keywords: Interest rate, output growth, monetary policy, Financial Sector Reforms, } \\
\text { Error Correction Mechanism. }\end{array}$ \\
\hline
\end{tabular}

\section{INTRODUCTION}

Interest rate is viewed from two perspectives: it is the price paid for borrowing money from a lender; as well as the rate of return associated with investing money or the cost of capital for borrowing money [1]. The role of interest rate in the real sector of the economy is linked to its impact on investments. Thus, it is seen as cost of borrowing or gain on lending. Traditionally, a rise in interest rate encourages people to save more thus creating a pool of loanable funds. However, an increase in interest rate also raises the cost of capital, resulting in a reduction in investment within the economy [2]. It becomes an imperative that, sustaining an interest rate that will favourable to both the savers and the investors is of top priority to the monetary authority. The Nigerian economy over the years has adopted several interest rate regimes, which include the regulated interest rate regime, the interest rate reform, and the market-based interest rate determination. The interest rate reform was aimed at promoting financial deepening.

Financial sector regulation in the Nigerian economy imposed ceiling on deposit and lending nominal interest rate at a low level relative to inflation; leading to low or negative interest rates that discourage savings mobilization and the channelling of mobilized savings through the financial system [3]. Such led to financial repression in the economy as postulated by [4] and [5]. Though interest rate should be kept relatively low to encourage investment, a negative real interest rate will have a significant impact on the quality and quantity of investment. Financial sector reforms were introduced to correct the problem caused by financial repression, and such reforms include interest rate liberation and the removal of ceiling and other controls on credit allocation [6].

Since interest rate is a key driver of investment and growth, a sustainable economic growth cannot be achieved when the rate of interest is quite high [7]. No wonder [8] opined that inflation rates and high interest rates are major drawbacks of economic growth in emerging economies. It therefore follows that even though a certain level of lending interest rate and inflation may be important in attracting investment, there is need to keep lending interest rate and inflation at a manageable limit in order to propel economic growth [3].

A look at the trend of real interest rate exhibits a tunnel-like structure in most of the years, and is therefore capable of discouraging savings and retarding growth in view of the empirical link between savings, investment and economic growth [9]. This is because a negative real interest rate will discourage savings that can be accessed for investment. This trend is presented 


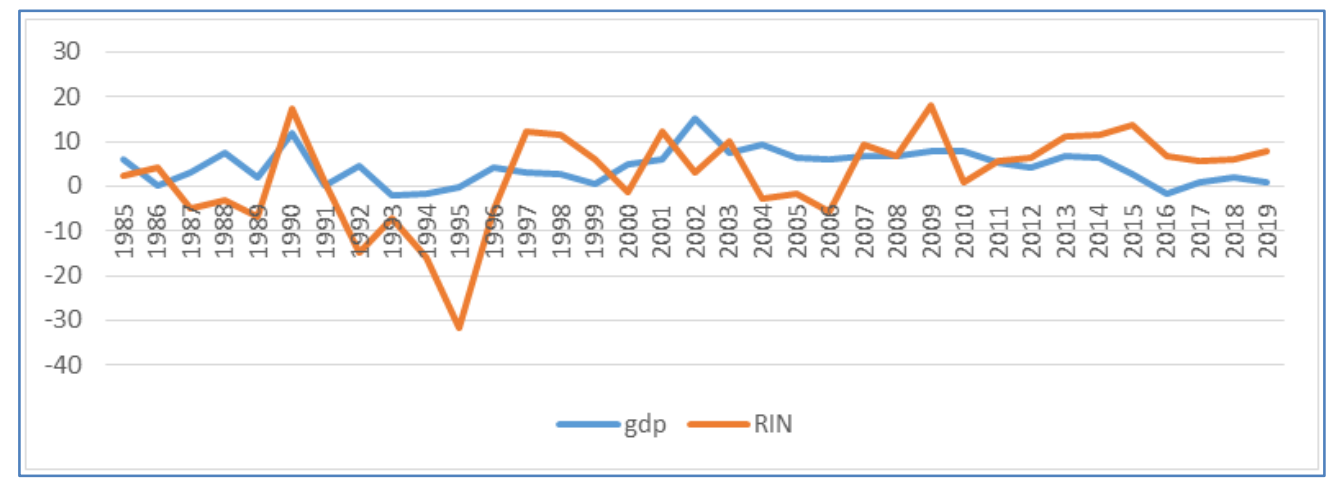

Fig-1: Trend of Growth Rate of Real Gross Domestic Product (gdp) and Real Interest Rate (RIN)

The real interest rate has been relatively low in the 1980s and mid 1990s with some years experiencing a negative real interest rate. For instance, the Nigerian economy experienced a negative real interest rate of $4.77 \%$ in 1987 and $-31.5 \%$ as at 1995 and this has been the lowest within the study period. This negative interest rate could have possibly dragged down savings and investment leading to poor economic growth. The economy also experienced negative interest rate as at 1988, 1999, 1992-1996, 2000, and 2004-2006. Periods of high interest rate such as 2013, 2014, and 2015 with real interest rate of $11.20 \%, 11.36 \%$, and $13.60 \%$ might have promoted savings but what will happen to investment with such a high interest rate? It is probable that investment will decline as entrepreneurs will shy away from such risky investment. This therefore point to the fact that the monetary authority has a significant role to play is maintaining a favourable interest rate through sound monetary policies. Sequel to the foregoing, the key question could be whether real interest rate significantly (whether positive or negative) affect real sector output growth in Nigeria.

The broad objective of this study is, therefore, to examine the effect of interest rate on real sector output growth in Nigeria. The study specifically seeks to:

- Determine the relationship between interest rate and growth rate of gross domestic product.

- To examine the effect of interest rate on the growth rate of gross domestic product in Nigeria.

- To investigate the existence/non-existence of a long run relationship between interest rate and real sector output growth in Nigeria.

The paper is structured in five Sections. Section I is the introduction which presents the background to the study while Section II is the literature review adumbrating both theoretical and empirical literature. Section III presents the methodology of the research while Section IV presents the empirical findings and discussion. Finally, Section V captures the conclusion of the study and the recommendation.

\section{LITERATURE REVIEW}

Several theories of interest rate have been discussed in the literature. Starting from the classical economist, the rate of interest is determined by the demand for and supply of capital. It follows that the rate of interest, under the classical school, is determined through the interaction of the demand curve and supply curve of savings. The points at which the two curves meet determine the equilibrium level of interest. If the rate of interest is above the equilibrium level, the demand for investment funds will fall and the supply of savings will rise. This creates an excess of savings leading to a fall in interest rate. Conversely, if the rate of interest is below the equilibrium level, the demand for savings will rise while the supply of savings will contract; creating an excess demand. This excess demand is what drives the interest rate upwards to return to the equilibrium rate.

In the neoclassical perspective, the rate of interest is determined by the demand for and supply of loanable funds. To them, the demand for loanable funds comes from the government, businessmen, and the consumers who demand for them for the purpose of investment, hoarding, and consumption. The supply too comes from savings, dishoarding and bank credit. The tendency to borrow is more at a lower rate of interest than at a higher rate. It is the interaction of the demand for loanable funds and the supply of loanable funds that will determine the rate of interest.

In the Keynesian realm, the rate of interest is determined just as the price of any commodity. It is determined at the level where the demand for money (liquidity preference) equals the supply of money. The demand for money is defined by the three motives for holding money - transaction, precautionary, and speculative - while the supply of money is fixed by the monetary authority. The interaction of the two curves determines the equilibrium rate of interest. If the supply of money is greater than the demand through an expansionary monetary policy and the liquidity preference remains the same, the adjustment is done through the interest rate. The interest rate will fall in 
this case. The opposite will suffice if money supply is contracted.

The modern theory of interest rate defines interest rate as being determined under the IS-LM framework. Thus, the interaction of the IS and LM curves determine the equilibrium level of income and interest rate. This theory captures the divergence in interest rate between the real market and the money market. An interest rate below the equilibrium level implies that the interest rate in the money market is less than that on the real sector. Thus, businessmen will borrow at a lower rate from the money market and invest the borrowed funds at a higher rate in the capital market. The resultant effect will be an increase in the level of income through the investment multiplier and the equilibrium level of interest will be restored. However, if the rate of interest is above the equilibrium rate, the rate of interest in the real market is less than the interest rate in the money market. It follows that businessmen will try to discharge debt $\mathrm{s}$ in the money market rather than invest in the capital market. Hence, investment will fall and reduce income by the multiplier and the equilibrium rate of interest will be restored.

Empirical studies on the effect of interest rate on the economic growth has captured the attention of researchers over the years [9]. Examined the relationship between interest rate and economic growth in Nigeria for 1970-2006. The study utilized cointegration and error correction model and the findings revealed that real lending rates have significant effect on economic growth. This was supported by [10] who found that the relationship between interest rate and investment in Nigeria is negative and thus affect economic growth.

Obamuyi, T. M. and S. Olorunfemi [6] studied the implications of financial reform and interest rate behaviour on economic growth in Nigeria for the period 1970 - 2006. The study employed the co-integration and error correction model and revealed that financial reform and interest rates have significant impact on economic growth in Nigeria.

In Iran, [11] investigated the relationship between interest rate and economic growth using time series panel data collected from 22 countries for the period $2004-2010$. Findings of the study showed that there was a negative relationship between interest rate and economic growth.

Using the OLS regression analysis for the period 1987-2009, [12] found that interest rates have insignificant association with economic growth in Nigeria. In the same vein, [3] examined the effect of interest rate fluctuation on the economic growth of Nigeria for the period 197-2010 using the Ordinary Least Squares multiple regression technique. The study revealed an inverse relationship between interest rate and economic growth in Nigeria. The study advocated for a strong monetary policy for Nigeria that would enhance lending to the real sector of the economy for productive economic activities.

Examined the impact of interest rate on economic growth in Nigeria for the period $1975-2008$ using OLS technique. The results indicated that interest rate exerted a negative impact on economic growth in Nigeria. They concluded that increase in interest rate retards investment and economic growth, while the lag of exchange rate shows the expected positive sign, implying that depreciation in exchange rate retarded economic growth [13].

In America, examined the relationship between interest rates and productivity growth using correlation estimation techniques. Their study revealed moderate correlation between interest rate and economic growth. The study specifically observed that in the long run, low interest rate will lead to high productivity growth while high interest rates would lead to low productivity [14].

In Jordan, [15] examined the effect of interest rate and inflation rate on real economic growth using time series data for the period $2000-2010$. The study utilized ADF unit root test, Johansen co-integration test and regression analyse. They found out a positive effect of interest rate on economic growth.

In Kenya, a negative effect of interest rates on economic grown was obtained in the study conducted by [16] for the period 2003-2012. Similarly [17], examined the impact of interest rate deregulation on economic growth in Nigeria for the period 1986 to 2010. The study employed OLS technique and found that low interest rate stimulates and increase growth in real domestic product.

Etale, L. M. and P. E. Ayunkun [1] examined the relationship between interest rate and economic growth in Nigeria, using time series panel data for the period 1985 - 2014. The study employed Augmented Dicker-Fuller (ADF) unit root tests as well as Johansen co-integration test followed by Error Correlation Model (ECM) approach. The ECM revealed that interest rate is inversely related to economic growth, but the relationship is statistically insignificant.

Ajayi, S. A., O. A. Oladipo, L. B. Ajayi and T. I. Nwanji [18] assessed the effect of interest rate on economic growth in Nigeria using the error correction approach and Granger causality test. The study revealed an existence of a long run relationship between interest rate and economic growth. The study further revealed that there exists causal relationship between savings deposit and GDP; and bidirectional causality between real interest rate and GDP. 
Similarly, [19] investigated the impact of interest rate on economic growth of Nigeria for the period 1990 to 2013. The findings revealed that interest rate has a slight impact on growth; however, the growth can be improved by lowering the interest rate which will increase investment.

Utile, B. M., A. O. Okwori and M. D. Ikpambese [20] investigated the effect of interest rate on the economic growth of the Nigeria for the period
1980-2016 using multiple regression approach. The study concludes that interest rate has a negative and insignificant relationship with GDP.

\section{Methodology}

In examining the effect of interest rate on real sector output growth, the functional form of the model is specified as follows:

$g d p=f(\mathrm{CAP}, \mathrm{LAB}, \mathrm{RIN}, \mathrm{INF}, \mathrm{MSG}, \mathrm{GOV}, \mathrm{EXC})$

Where:

gdp $=$ Growth Rate of Gross Domestic Product (a proxy for real sector output growth)

CAP = Gross Fixed Capital Formation (a proxy for capital)

LAB = Population aged $15-64$ years as a percentage of total population (a proxy for labour)

RIN = Real Interest Rate
$\mathrm{INF}=$ Consumer Price Index (a proxy for inflation)

MSG = Growth Rate of Broad Money Supply

GOV $=$ Growth Rate of Total Government Expenditure

$\mathrm{EXC}=$ Exchange Rate

Transforming Equation (1) into a double log function in its stochastic form, we then have

$\operatorname{gdp}=\beta_{0}+\beta_{1} \log \mathrm{CAP}+\beta_{2} \mathrm{LAB}+\beta_{3} \mathrm{RIN}+\beta_{4} \mathrm{INF}+\beta_{5} \mathrm{MSG}+\beta_{6} \mathrm{GOV}+\beta_{7} \mathrm{EXC}+\mu$

Where $\beta_{0}$ to $\beta_{7}$ are the parameters to be estimated; and $\mu$ is the random error term. Notice that gdp, LAB, RIN, MSG, GOV, and EXC are not in their log form due to the fact that they are all rates.

Data for the study were obtained from secondary sources. The [21] publication on World Development Indicators and the 2019 statistical bulletin from the [22] serves as the reference points for the data collected. The data was obtained for variables in the study which include growth rate of real gross domestic product, gross fixed capital formation, labour force,

$\Delta X_{t}=\alpha_{i}+\beta_{\mathrm{i}} X_{t-1}+\sum_{j=1}^{k} \gamma_{i j} \Delta X_{t-j}+\mu_{t}$

$\Delta X_{t}=\alpha_{i}+\beta_{\mathrm{i}} X_{t-1}+\delta \mathrm{t}+\sum_{j=1}^{k} \gamma_{i j} \Delta X_{t-j}+\mu_{t}$

Where $\mathrm{X}$ is the variable of interest in which the test is to be conducted; $\Delta$ captures the difference operator; while $\mathrm{t}$ is time.

The test for long run relationship is conducted using the Johansen co-integration test. The test utilizes the Trace statistic and Max-Eigen statistic in making inference on the existence of any long run relationship. It is expected that for a long run relationship to exist, there must be at least one co-integrating equation. The interest rate, inflation rate, growth rate of broad money supply, growth rate of total government expenditure, and exchange rate.

The technique of analysis follows the unit root test, co-integration test and the vector error correction mechanism. The unit root follows the Augmented Dickey-Fuller test approach with constant without trend (see Equation 3a) and with constant and trend (see Equation $3 b$ ) which is specified in its general form as follows:

$\Delta g d p_{t}=\varphi+\sum_{i=1}^{m} \beta_{1} \Delta C A P_{t}++\sum_{i=1}^{m} \beta_{2} \Delta L A B_{t}+\sum_{i=1}^{m} \beta_{3} \Delta R I N_{t}+\sum_{i=1}^{m} \beta_{4} \Delta I N F_{t}+\sum_{i=1}^{m} \beta_{5} \Delta M S G_{t}+\sum_{i=1}^{m} \beta_{6} \Delta G O V_{t}+$ $\sum_{i=1}^{m} \beta_{7} \Delta E X C_{t}+\lambda_{i} E C T_{t-1}+\mu_{i, t}$

Where is the optimal lag length selected based on the Schwarz Information Criterion (SIC) and ECT is the error correction term which must be negative and statistically significant.

\section{EMPIRICAL FINDINGS AND DISCUSSION}

The result from the empirical findings is presented first by analysing the unit root properties of 
the series followed by co-integration. Then the vector error correction model is estimated then to ascertain both the short run and long run relationship.
The result of the unit root test is presented in Table 1.

Table-1: Augmented Dickey-Fuller Unit Root Test Result

\begin{tabular}{|c|c|c|c|c|c|c|}
\hline \multicolumn{3}{|c|}{ Constant Assumption } & \multicolumn{4}{|c|}{ Constant and Deterministic Trend Assumption } \\
\hline Variable & $\begin{array}{c}\text { ADF Statistic } \\
\text { @ Level }\end{array}$ & $\begin{array}{l}\text { ADF Statistic @ } \\
\text { First Difference }\end{array}$ & $\begin{array}{c}\text { Order of } \\
\text { Integration }\end{array}$ & $\begin{array}{c}\text { ADF Statistic } \\
\text { @ Level }\end{array}$ & $\begin{array}{l}\text { ADF Statistic @ } \\
\text { First Difference }\end{array}$ & $\begin{array}{c}\text { Order of } \\
\text { Integration }\end{array}$ \\
\hline gdp & $\begin{array}{c}-3.863 \\
(0.005)^{* *}\end{array}$ & $\begin{array}{c}-10.636 \\
(0.000)^{* * *}\end{array}$ & $\mathrm{I}(0)$ & $\begin{array}{c}-3.810 \\
(0.028) * *\end{array}$ & $\begin{array}{c}-3.807 \\
(0.029)^{* *}\end{array}$ & $\mathrm{I}(0)$ \\
\hline CAP & $\begin{array}{l}-2.223 \\
(0.202)\end{array}$ & $\begin{array}{c}-4.495 \\
(0.001) * * *\end{array}$ & $\mathrm{I}(1)$ & $\begin{array}{c}0.165 \\
(0.996)\end{array}$ & $\begin{array}{c}-5.830 \\
(0.000)^{* * *}\end{array}$ & $\mathrm{I}(1)$ \\
\hline LAB & $\begin{array}{c}-4.584 \\
(0.001)^{* * *}\end{array}$ & $\begin{array}{c}-2.854 \\
(0.061)^{*}\end{array}$ & $\mathrm{I}(0)$ & $\begin{array}{c}-3.826 \\
(0.030) * *\end{array}$ & $\begin{array}{l}-2.764 \\
(0.223)\end{array}$ & $\mathrm{I}(0)$ \\
\hline RIN & $\begin{array}{c}-3.507 \\
0.013)^{* *}\end{array}$ & $\begin{array}{c}-7.298 \\
(0.000)^{* * *}\end{array}$ & $\mathrm{I}(0)$ & $\begin{array}{c}-4.080 \\
(0.015)^{* *}\end{array}$ & $\begin{array}{c}-7.188 \\
(0.000)^{* * *}\end{array}$ & $\mathrm{I}(0)$ \\
\hline MSG & $\begin{array}{c}-3.297 \\
(0.022) * *\end{array}$ & $\begin{array}{c}-6.020 \\
(0.000) * * *\end{array}$ & $\mathrm{I}(0)$ & $\begin{array}{c}-3.489 \\
(0.056)^{*}\end{array}$ & $\begin{array}{c}-5.990 \\
(0.000)^{* * *}\end{array}$ & $\mathrm{I}(1)$ \\
\hline INF & $\begin{array}{l}-2.261 \\
(0.190)\end{array}$ & $\begin{array}{c}-3.381 \\
(0.021)^{* *}\end{array}$ & $\mathrm{I}(1)$ & $\begin{array}{l}-2.756 \\
(0.224)\end{array}$ & $\begin{array}{c}-4.240 \\
(0.013) * *\end{array}$ & $\mathrm{I}(1)$ \\
\hline GOV & $\begin{array}{c}-1.497 \\
(0.521) \\
\end{array}$ & $\begin{array}{c}-3.669 \\
(0.010)^{* * *}\end{array}$ & $\mathrm{I}(1)$ & $\begin{array}{c}-9.448 \\
(0.000)^{* * *}\end{array}$ & $\begin{array}{c}-3.555 \\
(0.052)^{*}\end{array}$ & $\mathrm{I}(0)$ \\
\hline $\mathrm{EXC}$ & $\begin{array}{c}1.074 \\
(0.996)\end{array}$ & $\begin{array}{c}-4.051 \\
(0.003)^{* * * *}\end{array}$ & $\mathrm{I}(1)$ & $\begin{array}{c}-2.280 \\
(0.4325)\end{array}$ & $\begin{array}{c}-4.195 \\
(0.011)^{* *}\end{array}$ & $\mathrm{I}(1)$ \\
\hline
\end{tabular}

Source: Output extracted from Eviews 10.

Note: $* * *, * *$, and $*$ denotes significance at the $1 \%, 5 \%$, and $10 \%$ level respectively. Probabilities are in parenthesis () .

The result of the unit root test indicates that the variables are in mixed order of integration as reported by the ADF statistic. For instance, gdp under the constant assumption and constant and trend assumption is stationary at level since the ADF statistic is negative and statistically significant at the $5 \%$ level of significance. Hence, gdp is an $\mathrm{I}(0)$ variable. Other variables such as LAB, RIN, and MSG are all stationary at level under the constant assumption. Variables like CAP, INF, GOV, and EXC are all stationary at first difference under the constant assumption hence, they are all I(1) series. However, the result from the two assumptions is contradictory in some cases. For instance, MSG is stationary at level under the constant assumption but stationary at first difference under the constant and deterministic trend assumption. Similarly, GOV is stationary at first difference under the constant assumption but stationary at level under the constant and deterministic trend assumption. This mixed order of integration therefore necessitates the conduct of a cointegration test to detect whether the variables exhibit any form of long run relationship. In doing this, the Johansen Co-integration test and the ARDL Bounds test for levels are carried out.

The result of the co-integration test is presented in Table 2. The result of the Johansen cointegration reveals the existence of long run relationship.

Table-2: Co-integration Test Result

\begin{tabular}{|c|c|c|c|c|c|c|}
\hline $\begin{array}{c}\text { Hypothesized } \\
\text { Number of } \\
\text { Cointegrating } \\
\text { Equations CE(s) }\end{array}$ & Trace Test & $\begin{array}{c}\mathbf{5 \%} \\
\text { Critical } \\
\text { Value }\end{array}$ & Probability & $\begin{array}{l}\text { Max-Eigen } \\
\text { Test }\end{array}$ & $\begin{array}{c}\text { 5\% } \\
\text { Critical } \\
\text { Value }\end{array}$ & Probability \\
\hline $\mathrm{r}=0$ & 236.0715 & 159.5297 & $0.0000 * * *$ & 69.54416 & 52.36261 & $0.0004 * * *$ \\
\hline $\mathrm{r}>1$ & 166.5274 & 125.6154 & $0.0000^{* * *}$ & 56.55997 & 46.23142 & $0.0029 * * *$ \\
\hline $\mathrm{r}>2$ & 109.9674 & 95.75366 & $0.0037 * * *$ & 36.27471 & 40.07757 & 0.1261 \\
\hline $\mathrm{r}>3$ & 73.69266 & 69.81889 & $0.0237 * *$ & 33.50403 & 33.87687 & $0.0553 * *$ \\
\hline $\mathrm{r}>4$ & 40.18863 & 47.85613 & 0.2158 & 18.25356 & 27.58434 & 0.4741 \\
\hline $\mathrm{r}>5$ & 21.93507 & 29.79707 & 0.3021 & 11.80692 & 21.13162 & 0.5668 \\
\hline $\mathrm{r}>6$ & 10.12815 & 15.49471 & 0.2710 & 8.316637 & 14.26460 & 0.3474 \\
\hline $\mathrm{r}>7$ & 1.811511 & 3.841466 & 0.1783 & 1.811511 & 3.841466 & 0.1783 \\
\hline
\end{tabular}

Source: Output extracted from Eviews 10.

Note: ***, and ** denotes significance at the $1 \%$, and $5 \%$, level respectively. 
The result shows that there are series of co-integrating equations. For example, the Trace test shows that there are four co-integrating equations at the $5 \%$ critical value. This is obtained from the fact that the Trace statistic is greater than the $5 \%$ critical value and the probability of accepting the null hypothesis of no cointegration is quite slim represented by the probability values. Similarly, the Max-Eigen test reveals the existence of three co-integrating equations making us to reject the null hypothesis of no co-integration.

In validating the result of the Johansen cointegration test, the ARDL Bounds test for cointegration is presented in Table 3.

Table-3: Bounds Test for Co-integration

\begin{tabular}{|l|c|c|c|c|}
\hline \multicolumn{2}{|l|}{ F-Bounds Test } & \multicolumn{3}{|c|}{ Null Hypothesis: No levels relationship } \\
\hline Test Statistic & Value & Significance & $\begin{array}{c}\text { Lower Bound } \\
\mathrm{I}(0)\end{array}$ & $\begin{array}{c}\text { Upper Bound } \\
\mathrm{I}(1)\end{array}$ \\
\hline F-statistic & 8.484 & $10 \%$ & 1.92 & 2.89 \\
\hline $\mathrm{k}$ & 7 & $5 \%$ & 2.17 & 3.21 \\
\hline & & $2.5 \%$ & 2.43 & 3.51 \\
\hline & & $1 \%$ & 2.73 & 3.9 \\
\hline
\end{tabular}

Source: Output extracted from Eviews 10.

The Bounds test also reveals that there is levels relationship. This is because the F-statistic (8.484) is statistically significant at the $1 \%$ level of significance as it is greater than all the critical values at both the upper and lower bounds at the respective level of significance. Thus, the null hypothesis of no levels relationship is rejected. Based on the fact that the Johansen cointegration test and the Bounds test for level relationship reveals a strong evidence of a long run relationship. We proceed to estimating the error correction model and the result is presented in Table 4.

Table-4: Vector Error Correction Mechanism

\begin{tabular}{|c|c|c|c|c|}
\hline Variable & Coefficient & Standard Error & t-statistic & Probability \\
\hline$D(\log C A P)$ & 0.755 & 3.022 & 0.249 & 0.8078 \\
\hline$D(\log C A P(-1))$ & 11.796 & 3.053 & 3.862 & $0.0031^{* * *}$ \\
\hline$D(L A B)$ & -11.752 & 4.587 & -2.562 & $0.0283 * *$ \\
\hline$D(L A B(-1))$ & -20.174 & 4.542 & -4.441 & $0.0013 * * *$ \\
\hline$D(R I N)$ & -0.274 & 0.047 & -5.787 & $0.0002 * * *$ \\
\hline$D(R I N(-1))$ & -0.267 & 0.053 & -5.035 & $0.0005 * * *$ \\
\hline$D(M S G)$ & 0.015 & 0.021 & 0.700 & 0.4994 \\
\hline$D(M S G(-1))$ & 0.080 & 0.021 & 3.684 & $0.0042^{*} *$ \\
\hline$D(I N F)$ & 0.047 & 0.034 & 1.371 & 0.2003 \\
\hline$D(I N F(-1))$ & -0.074 & 0.035 & -2.067 & $0.0656 *$ \\
\hline$D(G O V)$ & -0.023 & 0.013 & -1.709 & 0.1182 \\
\hline$D(G O V(-1))$ & 0.074 & 0.015 & 4.768 & $0.0008 * * *$ \\
\hline$D(E X C)$ & -0.088 & 0.018 & -4.668 & $0.0009 * * *$ \\
\hline$D(E X C(-1))$ & 0.043 & 0.019 & 2.252 & $0.0480^{* *} *$ \\
\hline$E C T(-1)$ & -0.599 & 0.119 & -5.020 & $0.0000^{*} * *$ \\
\hline R-squared $=0.9136$ & \multicolumn{5}{|c|}{ Durbin-Watson Statistic = 1.654} \\
\hline
\end{tabular}

Note: ***, **, and * denotes significance at the 1\%, 5\%, and $10 \%$ level respectively.

Source: Output extracted from Eviews 10.

The result of the error correction model validates our result obtained from the co-integration test. This is because our error correction term (ECT) is negative and statistically significant at the $1 \%$ level. The coefficient $(-0.599)$ implies that $59.9 \%$ of the short run deviations or disequilibrium in real sector out growth is corrected annually. Since $59.9 \%$ is corrected annually, it therefore implies that it will take about two years for equilibrium to be fully restored. The Rsquared (0.9136) means that $91.36 \%$ of the total variations in real sector output growth is explained by variations in the explanatory variables in the model.
Also, the Durbin-Watson statistic (1.654), which is approximately 2.0 , is an indication of no serial correlation.

Based on the coefficients, it is observed that the previous period changes in capital exert a positive and significant effect on real sector output growth. Thus, the previous period changes in capital increases gdp by $11.752 \%$. Also, labour is observed to exert a negative and significant effect on gdp. However, it is expected that labour should exert a positive effect on real sector output growth due to its importance in the 
production process. This negative and significant effect of labour on gdp can be attributed to the high rate of unemployment inherent in the Nigerian economy. Such leads to the underutilization of available human capital which therefore impedes growth.

Real interest rate is observed to exert a negative and significant effect on real sector output growth at both its present and past period. A unit percentage increase in interest rate will lead to $0.274 \%$ decrease in real sector output growth. This finding therefore stresses the importance of effectively managing the rate of interest so as to be borrowerfriendly. A high interest rate is an indication of a greater cost of capital that will ward off investors from borrowing to invest. Since investment is a key driver of growth, a fall in investment as a result of high interest rate will lead to a decline in real sector output growth.

The previous period growth rate of broad money supply is also observed to be exerting a positive and significant effect on real sector output growth. Thus, it increases gdp by $0.08 \%$. Money supply exerting a positive and significant effect on gdp arises from the fact that a high growth rate of money supply arising from an expansionary monetary policy will put a downward pressure on interest rate. This downward pressure will encourage investors to borrow more for productive ventures thus, leading to greater growth in the real sector output.

The present period inflation is observed to exert an insignificant effect on real sector output growth but its previous period does. Hence, the previous period inflation exerts a negative effect on real sector output growth while the present period exerts a positive but insignificant effect. This mixed direction can be attributed to the fact that inflation in the previous period was cost push (since it has a negative effect on growth) while current period inflation is demand pull (being positive). Demand pull inflation will encourage entrepreneurs to produce more to meet with the rising volume of demand hence; growth is promoted through mass production.

Government expenditure in the present period is observed to exert a negative but insignificant effect on real sector output growth. This can be linked to the widespread corruption in the public sector. Hence, there can be a lag in government expenditure programme. Meanwhile, the previous period growth rate of government expenditure exerts a positive and significant effect on real sector output growth. It follows that the previous period's growth rate of government expenditure increases real sector output growth by $0.074 \%$. This is an indication that it takes time for government's expenditure to exert a real effect on the economy.
Finally, exchange rate and its past value exert a significant effect on real sector growth. A unit percentage increase in the previous period exchange rate leads to a $0.043 \%$ increase in real sector output growth. This is an indication that a higher exchange rate can sprout domestic production and submerge excessive importation. However, the current period exchange rate reduces real sector output growth by $0.088 \%$ and this can be linked to high cost of importation of raw materials that can be used for domestic production.

\section{CONCLUSION}

This study examined the effect of interest rate on real sector output growth in Nigeria for the period 1985 to 2019. The study views interest rate as a cost of capital in the investment process. Thus, higher interest rate is believed to impede investment and real sector growth. In examining the effect of interest rate on real sector output growth, the study employed the vector error correction mechanism. Meanwhile, the data was trimmed from the effect of time by being subjected to a unit root test. The unit root test reveals that the variables are in mixed order of integration which, therefore, prompts the use of the co-integration test. The co-integration test reveals that there is a long run equilibrium relationship between interest rate and real sector growth. It was observed that a unit percentage increase in interest rate will lead to a $0.274 \%$ decrease in real sector output growth. The vector error correction mechanism indicated that $59.9 \%$ of the short run disequilibrium in real sector output growth is corrected annually. Our findings on the negative effect of interest rate on real sector output growth deviates from [15] who observed a positive effect of interest rate on economic growth in Jordan but agrees with previous studies that are discussed in the literature.

Since the paper observed a negative effect of interest rate on real sector output growth in Nigeria within the study period, it is therefore recommended that cheap monetary policy that will keep interest rate at a favourable level should be practiced so as to encourage investors to borrow. Such will encourage investors to borrow which in turn will stimulates investment in the productive sector of the economy hence, growth in the real sector is.

\section{REFERENCES}

1. Etale, L. M., \& Ayunkun, P. E. (2016). The relationship between interest rate and economic growth in Nigeria: An Error Correction Model (ECM) Approach. International Journal of Economics and Financial Research, 2(6), 24138533.

2. Mushtaq, S., \& Siddiqui, D. A. (2016). Effect of interest rate on economic performance: evidence from Islamic and non-Islamic economies. Financial Innovation, 2(9); 1-14. 
3. Udoka, C. O., \& Anyingang, R. A. (2012). The effect of interest rate fluctuation on the economic growth of Nigeria, 1970-2010. International Journal of Business and Social Science, 3(20): 295302.

4. Mckinnon, R. I. (1973). Money and capital in economic development. Washington, D.C.: Brookings Institution.

5. Shaw, E. (1973). Financial deepening in economic development. New York: Oxford University Press, 1973.

6. Obamuyi, T. M., \& Olorunfemi, S. (2011). Financial reforms, interest rate behaviour and economic growth in Nigeria. Journal of Applied Finance and Banking, 1(4), 39.

7. Abebiyi, M. A. (2002). The role of real interest rates and savings in Nigeria. First Bank of Nigeria Plc, quarterly review.

8. Okpe, I. (1998). Interest Rate and savings mobilization: An empirical investigation of financial repression hypothesis. An unpublished $M$. Sc Thesis. Dept. of Economics, Amadu Bello University Zaria.

9. Obamuyi, T. M. (2009). An investigation of the relationship between interest rates and economic growth in Nigeria, 1970-2006. Journal of economics and International Finance, 1(4), 093098.

10. Erega, P. B. (2010). Interest rate variation and investment in Nigeria. International Business Management, 4(2): 41 - 464.

11. Etale, L. M., \& Ayunku, P. E. (2016). The relationship between interest rate and economic growth in Nigeria: An Error Correction Model (ECM) approach. International Journal of Economics and Financial Research, 2(6), 127-131.

12. Itodo, A. I., Eche, E., \& Kamo, K. (2012). The impact of interest rate deregulation on Economic growth in Nigeria. IJE Journal, 6: 349 - 362.

13. Imoisi, A. I., Chika, U. P., \& Moses, O. L. (2012). An analysis of interest and exchange rates effect on the Nigerian economy: 1975-2008. Asian

Economic and Financial Review, 2(6): 648 - 57.

14. Hansen, B. E., \& Seshari, A. (2013). Uncovering the relationship between interest rates and economic growth, Ann Arbor MI: University of Michigan Retirement Research Centre (MRRC) Working Paper, 2013. WP 303: 1-18. http://www.mrrc.isr.umich.edu/publication/papers/ pdf/wp303.pdf

15. Saymeh, A. A. F., \& Orabi, M. M. A. (2013). The effect of interest rate inflation rate, GDP, on real economic growth rate in Jordan. Asian Economic and Financial Review, 3(3): 341-54.

16. Mutinda, D. M. (2014). The Effect of lauding interest rate on Economic growth in Kenya. A research project submitted in partial fulfilment of the requirements for the award of a degree of masters of Science in finance, University of Nairobi.

17. Ifeanyi, O. J., \& Chukwu, N.G. (2014). The nexus of interest rate deregulation and economic growth in Nigeria. International Journal of Empirical Finance, 3(3): 142-51.

18. Ajayi, S. A., Oladipo, O. A., Ajayi, L. B., \& Nwanji, T. I. (2017). Interest Rate and Economic Growth: The Case of Nigeria. International Review of Business Research Papers, 13(1), 141-150.

19. Maiga, F. K. (2017). Impact of interest rate on economic growth in Nigeria. Pyrex journal of business and finance management research, 3(3), 98-111.

20. Utile, B. J., Okwori, A. O., \& Ikpambese, M. D. (2018). Effect of interest rate on economic growth in Nigeria. International Journal of Advanced Academic Research, 4(1), 66-76.

21. World Bank. (2018). World Development Indicators.

22. Central Bank of Nigeria. (2019). Statistical Bulletin. 